\title{
3
}

\section{History, Legitimacy, and Motivation in Marmoutier's Literature for the Angevins}

Between about II 37 and II75 Marmoutier's monks wrote three works that served in part to enhance the status and legitimacy of the counts of Anjou. The first of those works glorified Ingelger, the legendary tenth-century patriarch of the Angevin line; the second, a history of the counts of Anjou, gave a series of brief biographies beginning with Count Ingelger and continuing through Count Geoffrey the Fair (d. IISI); and the third provided a laudatory biography of Geoffrey the Fair.

These three works reflect a growing interest, in the eleventh and twelfth centuries, in noble ancestry. Medieval people tended to believe that charged moments in the past-especially origin points, the times when patriarchs lived-provided blueprints and exemplary models for the present. But by the twelfth century they had also become convinced that tangible links should join the past with the present and that individuals derived their status and personality from their bloodlines. As the discussion in chapter 6 shows, this aristocratic concern with genealogy and linear continuity spilled over into monastic histories as well.

Legitimizing stories about the ancestors of a count or king not only could enhance that man's reputation but could also mold him, telling him who he was and how he should behave. Over the course of the twelfth century, Marmoutier's writings about the Angevins showed an increasing concern with molding behavior and affecting the conscience of the individual. This interweaving of an interest in collective reputation with an interest in interior motivation points to the close linking in this period of group consciousness and notions of the self, the one enhancing the other. Indeed, both the concern with group legitimacy and the awareness of individual responsibility were related, at least in part, to the mounting complexity of society.

Because they served persuasive purposes, Marmoutier's legends 
about the Angevins had the potential of meeting not only the Angevins' needs, but also those of the monks. Through their legends the monks offered moral advice, and they informed the counts of Anjou and the first Angevin king of England how to maintain reciprocal relations with the abbey. The monks portrayed these ideal relations at a time when the Angevins were turning to the newer religious orders for spiritual solace. It is possible that the monks saw in these texts (and especially in the Return from Burgundy) a way to draw the Angevins' attention back to Marmoutier and Martin's cult. Even if the monks failed in the end to outshine the newer religious orders in the Angevins' eyes, they could still benefit from the favor of their rulers in courts of law. By presenting the Angevins with the "gift" of flattering histories, the monks may have hoped to merit the reciprocal gift of favorable legal decisions if ever the need arose.

\section{Dynastic Legitimacy: Saint Martin's Return from Burgundy}

Marmoutier's first work concerning the counts of Anjou, the Return from Burgundy, was written by an anonymous monk between about II 37 and II 56.1 This legend enhanced the reputation of the counts of Anjou in three ways: it simultaneously associated their patriarch with the cult of Saint Martin and disassociated the Capetian king from that cult; it contrasted the heroism of Count Ingelger of Anjou with the ineffectual behavior of the king of Francia; and it made a substantial contribution to the Angevins' genealogical literature.

The criticism of an earlier king of France in the Return from Burgun$d y$ reflected the political stance of the Angevins in the years after I I 28 . Before I 28 the Angevins had frequently changed sides in the political struggles of the times, sometimes allying with the Capetian kings and sometimes lining up against them. In I 128 , however, a new phase of Angevin history began. Fulk Junior's son Geoffrey the Fair became engaged to Mathilda, the daughter of Henry I of England, and the Angevins turned their attentions to England. ${ }^{2}$ When Henry II, the son of Geoffrey and Mathilda, assumed the English throne in I I 54, Touraine became part of the Angevin empire, and it did not fall under the French king's domain until I 204.

In its focus on the prestige of the Angevins and its implicit crit-

I. On the date of the Return from Burgundy (De reversione beati Martini), see Source Appendix, I-A.

2. Guillot, Comte d'Anjou, I:56-ıor; Chartrou, Anjou de 1109 à 1151, I-25. 
icism of the French throne, the Return from Burgundy differed from the work that had inspired it-Radbod of Utrecht's sermon describing the siege of Tours in 903. Whereas Radbod's sermon had assumed that the community of Christian Franks was united and that it directed its hostility toward external enemies, the Return from Burgundy emphasized hostilities among Christians, thereby highlighting the twelfthcentury author's perception that both the church and Christian society in general were divided into competing communities or groups.

According to the legend, the special relationship between the Angevins and the cult of Saint Martin originated when Ingelger, allegedly the first count of Anjou, stepped in to fill a void left by the king, who through his inactivity implicitly forfeited his association with Martin. Abbot Herbern and the other men who had carried Martin's relics to Auxerre sought the assistance of the king, the legend claimed, when they learned that the bishop of Auxerre would not allow them to carry the relics back to Tours. The king, however, was reduced to inaction by his desire to avoid prejudicing one part of his kingdom in favor of another. He told the saint's custodians that both Tours and Auxerre were in his realm and that the evidence of possession seemed to favor Auxerre's claims: "Since both cities are under royal authority and in both we serve that authority indifferently, we consider it unworthy that with the violence of prejudice we should despoil Auxerre, which possessed the treasure, and that we should give it to Tours, which up until now has relinquished its possession."3 In the face of such unjust equanimity, the Return from Burgundy implied, it was better to turn to local patrons. Indeed, when the Tourangeaux turned to Count Ingelger for assistance, he immediately responded to their dilemma. Backed by the armed might of six thousand men and horses and assisted by several bishops, the count convinced the bishop of Auxerre to relinquish Martin's relics. He then accompanied Martin's party in its glorious procession back to Tours. 4

Earlier facts and traditions concerning the Angevin line had already established a special relationship between the Angevin line and Saint Martin's cult and basilica. Fulk the Red $(+940)$ had probably been the treasurer of the chapter of Saint-Martin (although this seems to have been forgotten by the twelfth century); Fulk the Good (+960) had, so

3. "Cum utraque civitas regii sit juris, et ab utraque nobis indifferenter serviatur, indignum ducimus ut Autissiodorum, quae de thesauri hujus possessione saisita est, praejudicii violentia spoliemus, et Turonum vestram, quae huc usque illius investituram amisit, investiamus" (De reversione beati Martini, 26).

4. De reversione beati Martini, 28-34. 
the twelfth-century Deeds of the Counts of Anjou claimed, such special devotion for the church of Saint-Martin that he was made an honorary canon there and frequently sang in the choir; Geoffrey Greymantle was buried at Saint-Martin; and Geoffrey Martel (as well as his descendants) carried the saint's banner into battle. 5 Nevertheless, legendary historiography now established that Ingelger was the patriarch of the Angevin line. Thus, because the prevailing historical consciousness of the period assumed that points of origin provided blueprints for subsequent time, Ingelger's relationship with Martin's cult was normative in a way that those of Fulk the Good, Geoffrey Greymantle, and Geoffrey Martel were not. 6

Furthermore, unlike the remembered devotion of Fulk the Good, the burial of Geoffrey Greymantle, and the use of Saint Martin's banner by Geoffrey Martel (who fought as an ally of the Capetian king the first time he carried Martin's banner, in I044), the Return from Burgundy indicated that the formation of the relationship between the Angevins and Saint Martin's cult was linked to the king's failure to live up to his responsibilities toward the saint. 7 Indeed, it appears that the author of the Return from Burgundy, mindful of his patron's com-

5. On Fulk the Red as treasurer of Saint-Martin, see John of Salerno, "Vita Sancti Odonis," I:I I, I:2 I, PL I 33:48, 52. John does not state outright that Fulk was the treasurer, but the actions he describes (Fulk gave Odo a cell at Saint-Martin and a canonry, and he took two gold vessels from the treasury) lend themselves to that conclusion. I am grateful to Barbara H. Rosenwein and Bernard S. Bachrach for alerting me to these passages. On Fulk the Good's honorary canonry, see Chronica de gestis consulum Andegavorum, 36. This twelf thcentury passage, perhaps an invention, may have been based on the fact that Guy, the brother of Fulk the Good, was indeed a canon at Saint-Martin: see Guillot, Comte d'Anjou, I 4 I n. 49; Chroniques des comtes d'Anjou, 33 n. 2. On Geoffrey Greymantle's burial, see Fulk Rechin, Fragmentum historiae Andegavensis, 233. On Geoffrey Martel and his descendants carrying the banner of Saint-Martin, see Ralph Glaber, Historiarum libri quinque, s:2, pp. I 29-30; Vaucelle, Collé giale de Saint-Martin, I 70; Du Cange, Glossarium, S.V. "Vexillum S. Martini," 6:796.

6. On the identification of Ingelger as the Angevin patriarch, see text below at note 20 ff. On historical consciousness and the importance of blueprints from the past, see Duby, "French Genealogical Literature: The Eleventh and Twelf th Centuries," in Duby, Chivalrous Society, 134-57, esp. I 56; Spiegel, Chronicle Tradition of Saint Denis, 40, 44-45; Chenu, "Monks, Canons and Laymen in Search of the Apostolic Life," in Chenu, Nature, Man and Society in the Twelfih Century, 202-38; Benson, "Political Renovatio: Two Models from Roman Antiquity"; Constable, "Renewal and Reform in the Religious Life"; Southern, "Aspects of the European Tradition of Historical Writing: 4. The Sense of the Past." Brian Stock associates both the preoccupation with anterior models or precedents and the efflorescence of genealogical literature with the growing importance and predominance of literacy: see "Medieval Literacy, Linguistic Theory, and Social Organization," 19, 25-26. But already in the early eleventh century there had been a concern with presenting the distant past as a blueprint for the present. See Landes, "Dynamics of Heresy and Reform in Limoges," 480.

7. On Geoffrey Martel's relations with King Henry I of France in I044, see Guillot, Comte d'Anjou, I:57-58. 
petitive stance toward the Capetian kings, was trying to promote a relationship between Saint Martin and the counts of Anjou that both rivaled the one between the Capetian king and Saint Denis and appropriated for the house of Anjou a saint who had traditionally been associated with the kings of Francia.

To a certain extent the Capetian kings themselves had already begun to abandon Martin's cult as they grew closer to the cult of Saint Denis. About a generation before the Return from Burgundy was written, during the reign of Louis VI, the link between the Capetian kings and Saint Denis began to receive greater attention than before. In I I24, under the threat of attack by the emperor Henry V, Louis visited the abbey of Saint-Denis, just outside Paris. There he declared that Denis was the special patron and protector of the realm and took up the saint's banner, which he intended to carry into battle. By the end of the twelfth century this banner was identified with the oriflamme, which Charlemagne had carried in the Song of Roland, and it remained a central royal symbol until the end of the Middle Ages. 8

But Louis might have chosen another saint. His predecessor Philip I, for instance, had favored Saint Remi's relationship with the crown and had chosen to be buried at Fleury, near Saint Benedict, who was also a long-standing favorite of the Frankish rulers. ${ }^{9}$ It is significant, however, that Louis VI, with the encouragement of Abbot Suger and other monks of Saint-Denis, chose a saint who resided within the immediate royal domain. Even though the events of I 24 gave rise to an unusual amount of unity between the king and his vassals, Louis VI's most direct sphere of activity remained his private domain-land in the region immediately around Paris. ${ }^{10}$ Such was the state of the feudal monarchy in the late eleventh and early twelfth centuries. By the time the king finally extended his unrivaled power over Touraine in 1204, Saint Denis had gained an unquestionable position as the royal patron.

Changes in the manuscripts of the liturgical acclamations of the king, the laudes regiae, may well reflect the twelfth-century rise of Saint Denis's royal status vis-à-vis that of Saint Martin. Eighth-

8. Spiegel, Chronicle Tradition of Saint Denis, 30; Spiegel, "Cult of St. Denis and Capetian Kingship," 58-59. Erdmann (Origins of the Idea of Crusade, 273-74) also maintained that the turning point in Denis's relationship with the king came in the eleventh and twelf th centuries, especially with the new role of Denis's banner.

9. Spiegel, Chronicle Tradition of Saint Denis, 28.

10. Hallam, Capetian France, I 14-19. On the role Suger and the monks of Saint-Denis played in promoting Denis's cult, see Bournazel, "Suger and the Capetians." See also Spiegel, "Cult of St. Denis and Capetian Kingship," 58-59. 
century Carolingian laudes had equated the two saints, associating them, as well as Saints Hilary and Maurice, with the Frankish army. In these manuscripts, and in one from the eleventh century as well, the king was associated with Saints Mary, Michael, Gabriel, Raphael, John, and Stephen. But in a twelfth-century manuscript the king was associated with Denis alone. ${ }^{11}$ Although the basilica of Saint-Martin of Tours remained a royal abbey and twelfth-century chansons de geste, such as the Couronnement de Louis, perpetuated the idea of the king's relationship with Martin, before the middle of the twelfth century Saint Denis attained a privileged position as the preeminent royal patron saint. 12

The monks of Marmoutier thus promoted an association between Saint Martin and the Angevins one generation after Louis VI and the monks of Saint-Denis began to stress with new fervor the relationship between Denis and the Capetian line. The efforts of both the monks of Marmoutier and those of Saint-Denis reflect a general intensification in the use of legitimizing legends and rituals. These resulted at least in part from the competitive relationship between princely magnates and the Capetian kings, whose power-from the time of Louis VI on-was growing at the expense of those magnates. In Tours, in the period when the Return from Burgundy was written, the Angevins were feeling the direct effects of the expansion of Capetian power. Between I044, when Geoffrey Martel gained control over Touraine, and the early part of the twelfth century, the men who were appointed deans and treasurers of the chapter of Saint-Martin tended to be close allies of the Angevins. The treasurer who assumed office about I I39, however, and possibly the dean who assumed office about i I 54, were sons of King Louis VI. And all their successors, at least until the end of the thirteenth century, were close allies of the Capetian kings. 13

In addition to associating the count of Anjou with Saint Martin's cult, the Return from Burgundy contributed to the status and prestige of the Angevins by portraying the founder of the line as a hero of the Viking era and by contrasting his heroism with the king's ineffectual behavior. The legend described Ingelger as an "energetic count" (comes impiger) and juxtaposed the count's energy with the "slothfulness"

I I. Kantorowicz, Laudes Regiae, is (citing Bibliothèque Nationale, MS. lat. I 3 I 59, eighth century), $46 \mathrm{n}$. I 8 (citing Rouen, Bibliothèque Municipale, MS. 537, twelf th century), I I6 n. I6 (citing Bibliothèque Nationale, MS. lat. 9949, eleventh century).

12. For Martin's relationship with the king in the chansons de geste, see Couronnemente de Louis, line 1467, p. 68; Frappier, Chansons de geste du cycle de Guillaume d'Orange, 2:I49.

I 3. Griffiths, "Capetian Kings and St. Martin of Tours," I I 5-17, I26-27. 
(pigra segnities) that prevented the king from protecting the interests of the Tourangeaux. ${ }^{14}$

In focusing on a hero of the era of Viking and Saracen invaders, as well as in contrasting a vigorous count with a passive sovereign, the Return from Burgundy resembled a number of chansons de geste, also written in the first half of the twelfth century. The Couronnement de Louis, for example, portrayed the emperor Louis the Pious as a thoroughly incompetent ruler whose realm was held together and protected by Count William of Orange, who fought the Saracen invaders and defended both the Christian faith and the principle of justice. 15

Some critics have argued that the portrayal of a weak king in many of the chansons de geste represented the perspective of powerful territorial lords who either threatened or were threatened by the increasing effectiveness of the French kings. Twelfth-century vernacular literature promoted the interests of these rivals to the Capetians by reducing the sovereign to a weak figurehead or portraying him as an unjust antagonist. 16 The Return from Burgundy can also be understood in this way. It was written at the same time as these chansons de geste, it glorified a comital family that was in direct competition with the Capetians, and it juxtaposed an energetic count, who performed his heroic deeds during the mythical age of Viking and Saracen invaders, with an ineffective and slothful king.

But Ingelger's heroism represents more fundamental intellectual shifts as well. Unlike Radbod's tenth-century sermon, in which the Franks were passive victims and only God and his saints played active roles, the Return from Burgundy portrayed men as actors. Ingelger proved his faith with acts of prowess and bravery. In Radbod's account, the appearance of Martin's relics had caused a "vehement stupor" to strike the Danes; in the Return from Burgundy, by contrast, it was at the appearance of Ingelger's armed band that "the city of Auxerre was stupefied." 17 This emphasis on men as causal agents

14. De reversione beati Martini, 27-28. For a similar eleventh-century portrayal of the lazy king, see the Annales de Vendôme, cited by Dunbabin, France in the Making, I33.

I5. Couronnement de Louis; Frappier, Chansons de geste du cycle de Guillaume d'Orange, 2:5I.

16. Calin, Old French Epic of Revolt, I 3 I; Bezzola argues that the noble criticism was not that the king had too much power, but that he could not maintain control: see "De Roland à Raoul de Cambrai." R. Howard Bloch sees in all the epics more a criticism of war as a means of solving problems in the post-feudal age than a criticism of monarchy (Medieval French Literature and Law, 100-103).

17. "Danis e contrario stupor vehemens incussus est" (Radbod, Libellus de miraculo $S$. Martini, 1243); "Stupet Autissiodorum civitas armato milite ex insperato se repleri" (De reversione beati Martini, 28). 
points to one of the salient characteristics of spiritual and secular writings from the period that began about I000-optimism. 18

Insofar as it reflected the competition between the French king and the princely magnates of his realm, the Return from Burgundy resembled not only certain themes in the chansons de geste but also new historical writings. ${ }^{19}$ Such writings, which emanated from both royal and noble circles, also served legitimizing purposes. The most important innovation within this genre entailed the emergence of noble genealogies and genealogical histories, to which the Return from Burgundy contributed.

Between the seventh century and the eleventh century the only genealogies recorded in continental Europe were produced for royal dynasties. At the end of the eleventh century, however, a few powerful noble families-those of the counts of Anjou and Flanders and that of the duke of Normandy-began to record or commission their own genealogies. In these works the powerful magnates claimed (whether or not it was true) that their lineages had originated in Carolingian times and that they thereby owed their power and office not to the Capetian king but to their own connections with the Carolingians, which had been preserved through the unbroken links of their continuous family lines.

The initial function of the new genealogies was to illustrate the continuity of a patrimony, passed on through a single bloodline. In the twelfth century, however, the circle around the Angevins, like those around other powerful nobles, became interested in recording the deeds of ancestors who had bequeathed to them an inheritance of valor as well as a patrimony. Indeed, the accounts of these deeds suggested that it was by virtue of their heroic accomplishments in the mythical age of Carolingian rulers and pagan invaders that legendary ancestors had obtained their patrimonies. Twelfth-century family histories like those concerning the Angevins both borrowed from and provided material for the chansons de geste.

The gradual elaboration of the historical accounts concerning In-

18. This new confidence in man as actor is implicit in several discussions of the twelf thcentury renaissance and twelfth-century spirituality. See, for example, Southern, Making of the Middle Ages, 219-57; Chenu, "Nature and Man," in Chenu, Nature, Man, and Society in the Twelfth Century, I-48.

19. For the following discussion, see Duby, "Structure of Kinship and Nobility" and "French Genealogical Literature," in Duby, Chivalrous Society, 134-57; Spiegel, "Genealogy: Form and Function," 45-53; Spiegel, Chronicle Tradition of Saint Denis, 40, 44-45; Lewis, Royal Succession in Capetian France, I 19-20. On the development of patrilineal consciousness in twelfth-century Germany, see Freed, Counts of Falkenstein. 
gelger illustrates the stages of development of these family histories. Ingelger's historical existence is affirmed by a ninth-century charter in which he is identified as the father of Fulk the Red, the first historical count of Anjou. 20 More than a century after Ingelger's death, the Angevins began to take an interest in recording the history of their line. Not surprisingly, however, their memory of the family patriarch was weak. To be sure, they still knew who Ingelger was: his name appeared on one of the earliest Angevin genealogies, written at the abbey of Saint-Aubin of Angers toward the end of the eleventh century. ${ }^{21}$ Even so, Fulk Rechin, who wrote a short history of his family in I096, said he could record the "virtues and deeds" neither of Ingelger nor of Ingelger's two successors, Fulk the Red and Fulk the Good, "because they lived so long ago that we do not even know where they are buried." 22 Nevertheless, Fulk Rechin contributed to, and perhaps initiated, the family mythology concerning Ingelger, claiming that it was a descendant of Charlemagne, rather than an ancestor of the Capetians, who had bestowed the position of count on Ingelger. Fulk Rechin also claimed that Ingelger, as well as his earliest descendants, had liberated Anjou from pagans: "These four counts [Ingelger, Fulk the Red, Fulk the Good, and Geoffrey Greymantle] held the honor of Anjou, having seized it from the hands of pagans. . . . And Ingelger, the first count, held that honor from the king of France-not from the race of the impious Philip [who had recently won over and married Fulk's wife] but from the stock of Charles the Bald, who was the son of Louis, the son of Charlemagne."23

During the first half of the twelfth century, historians of the Angevin line elaborated the legends concerning Ingelger. According to

20. Halphen, Comté d'Anjou, 3; Cartulaire de l'abbaye de St. Aubin d'Angers, 177; Werner, "Untersuchungen zur Frühzeit des französischen Fürstentums," 266-79. For a recent assessment of Werner, with some discussion of Ingelger and Fulk the Red, see Bouchard, "Origins of the French Nobility," S14-16.

21. Genealogiae comitum Andegavensium, 247.

22. "Quorum quatuor consulum [Ingelger, Fulk the Red, Fulk the Good and Geoffrey Greymantle] virtutes et acta, quia nobis in tantum de longinquo sunt ut etiam loca ubi corpora eorum jacent nobis incognita sint, digne memorare non possumus" (Fulk Rechin, Fragmentum historiae, 233). Although Fulk included Geoffrey Greymantle in this statement, he went on to explain that Geoffrey was an exception because he was the most recent of the four, and indeed, Fulk knew where Geoffrey was buried.

23. "Isti autem quatuor consules tenuerunt honorem Andegavinum et eripuerunt eum de manibus paganorum et a christianis consulibus defenderunt. Et ille primus Ingelgerius habuit illum honorem a rege Francie, non a genere impii Philippi sed a prole Caroli Calvi, qui fuit filius Hludovici filii Caroli Magni" (Fulk Rechin, Fragmentum historiae, 232-33). On the earlier evidence concerning the first Angevin counts and the Capetians, see Bouchard, "Origins of the French Nobility," sis. 
the first redaction of the Deeds of the Counts of Anjou, written before I I 5 and rewritten after I I II, Ingelger defeated the Vikings in battle, thereby earning himself a noble wife, additions to his patrimony, and the position of count. Concerning Ingelger's chivalric behavior, this work noted that while he was still a youth, Ingelger successfully defended in one-on-one combat his godmother, who had been falsely accused of adultery. 24

The Return from Burgundy augmented the Angevins' corpus of genealogical literature and elaborated the themes that had been important to Fulk Rechin and the first author(s) of the Deeds of the Counts of Anjou. Like the earlier histories, it rooted the family memory in the age of Carolingians and Vikings and portrayed the patriarch of the line as a chivalric hero. It enhanced those themes by demonstrating that the association between the Angevins and the cult of Saint Martin began with Ingelger.

But unlike Fulk Rechin's fragment and the first version of the Deeds of the Counts of Anjou, the Return from Burgundy was written from a decidedly monastic perspective. As I argued in chapter 2, the legend helped support the interests of Marmoutier and Saint-Martin in their struggles with the archbishop of Tours. Even while glorifying Marmoutier's Angevin patrons, moreover, the legend attempted to mold those patrons by instructing them that they should protect the monks and canons who guarded Saint Martin's cult. The message applied to both Marmoutier and Saint-Martin. By emphasizing that the party in Auxerre was headed by Abbot Herbern of Marmoutier, however, the author highlighted the relationship between Marmoutier and the counts.

The monastic perspective of the Return from Burgundy is perhaps best illustrated by the fact that the monks themselves (along with their companions from Saint-Martin) were the principal beneficiaries of the deeds and miracles in the story. This had not been so in earlier stories about the Angevins' relations with the cult of Saint Martin or in the earlier histories of the Angevins. In an eleventh-century account of Geoffrey Martel's victory in I044 over the count of Blois, the miracles of Saint Martin benefited the count: in I044 when Geoffrey first carried Martin's banner into battle, he won the battle without

24. Chronica de gestis consulum, 29-31. On the dates of the first redaction (which was written by Thomas of Loches, chaplain for the Angevin count, and then rewritten by a certain Robin), see Chroniques des comtes d'Anjou, xviii-xxxix, and Martin, "Autour de Thomas Pacitius, prieur de la collégiale de Loches." Martin argues that Thomas must have written bef ore i i s 5 because he would have sof tened his harsh portrayal of Bertrade-who left Fulk Rechin to marry King Philip-once she became a prioress at Fontevrault in I I Is. 
shedding any blood because Thibaud of Blois's men were frightened by Geoffrey's army, which looked completely white. 25 Similarly,in Fulk Rechin's historical fragment and in the first version of the Deeds of the Counts of Anjou, Ingelger's actions were beneficial to himself, bringing him wealth, property, and the position of count. In the Return from Burgundy, Ingelger's action served the monks, the canons of Saint-Martin, and the saint himself. And the miracles in that legend reinforced the idea that Ingelger's service and the consequent return of the saint's relics to Tours were pleasing to God and to Martin. When the saint reentered his parish, bells rang, candles ignited, and trees turned green in mid-December. ${ }^{26}$

In its representation of the heroic patriarch Ingelger, the Return from Burgundy emphasized the layperson's responsibility to protect the interests of religious institutions. Nevertheless, like the more secular works about heroic ancestors, the legend concentrated on external behavior and external signs of status. Like an epic hero, Ingelger established his reputation through actions: we know nothing about his motivations or sentiments. 27 Ingelger's external accomplishments devolved, as an almost physical inheritance, upon the Angevin counts who succeeded him. But the legend about Ingelger was also an exemplary and exhortatory tale establishing a set of expectations for those who inherited the patriarch's position. Thus the author of the Return from Burgundy implied that a good count did not simply inherit his status; rather, he chose to conform to the model of his ancestors. John of Marmoutier would go much further in this exhortatory and motivational direction.

Group Legitimacy and Individual Motivation:

The Writings of John of Marmoutier

In his writings about the Angevin line John of Marmoutier, like the author of the Return from Burgundy, legitimized his secular patrons while at the same time adding a monastic perspective. Also like the earlier author, John strengthened the links between his Angevin patrons and the cult of Saint Martin. Unlike the earlier author, however, John shifted his preoccupations away from heroic behavior, and his desire to mold the individual character of his patron, King Henry II of

25. Ralph Glaber, Historiarum libri quinque 5:2, pp. 129-30.

26. De reversione beati Martini, 32.

27. For a general discussion of epic heros and external concerns, see Southern, Making of the Middle Ages, 24I-46. 
England, was more explicit. John consciously employed the art of persuasion to incite Henry to be a good man. Although John's discussions of motivation and persuasion did not bear directly on the cult of Saint Martin, his interest in these themes merits our attention, since parallel discussions recurred in texts from Marmoutier that did involve Martin's cult.

Both of John's works-his revised and expanded version of the Deeds of the Counts of Anjou, which he wrote between I I64 and I I73, and his biography of Geoffrey the Fair, written after I I73-contributed to the corpus of Angevin genealogical literature. 28 Furthermore, John gave the Angevins' relationship to Martin's cult a central place in the family's genealogical memory by incorporating the Return from Burgundy into his redeaction of the Deeds of the Counts of Anjou. 29

John's inclusion of the earlier legend in the family's continuous linear history strengthened the implication that because the family patriarch was linked to Saint Martin's cult, so were all his descendants. And John reinforced this message of continuity by making a new claim that not only Ingelger, but also his first two descendants-the three ancestors whose bodies had been lost to Fulk Rechin seventy-five years earlierwere buried at Saint-Martin. ${ }^{30}$

John also asserted, as the Return from Burgundy did not, that the relationship between Ingelger and Martin's cult was reciprocal: he claimed that after Ingelger accompanied Martin's relics to Tours he was given a prebend at the basilica of Saint-Martin and designated its defender, tutor, and treasurer. Fulk the Red, the actual patriarch of the Angevin line, probably was the treasurer of Saint-Martin. But he apparently used the position on occasion to plunder the chapter's resources rather than to serve the house. Thus John's example differed from the historical precedent (which he may not have known anyway), in that he portrayed Ingelger as the defender of Saint-Martin. ${ }^{31}$

Not only in his narrative about Ingelger but also in his biography of Geoffrey the Fair, John was able to demonstrate that both the count and the religious houses of Marmoutier and Saint-Martin benefited

28. On the dates of John's works, see Chroniques des comtes d'Anjou, xxvi, xl, lxxxiv.

29. Chronica de gestis consulum, $30 \mathrm{n}$. d.

30. Chronica de gestis consulum, 3I n. a; 34 n. a; 37 n. a; and introduction, Chroniques des comtes d'Anjou, xi, xlvi.

31. Herbernus, Archbishop of Tours (attributed), Miracula beati Martini, PL I29:1035. This passage was either written by John of Marmoutier and borrowed by the author of the collection of miracles or vice versa. On the Herbernus collection, see Van der Straeten, "Recueil de miracles de S. Martin attribué à Herberne." John put this passage at the end of the passages that he borrowed from the Retum from Burgundy: see Chronica de gestis consulum, 30, n. d. On Fulk the Red, see above at note s. 
from their association. According to John, the archbishop of Tours threatened to excommunicate Geoffrey during one of their frequent altercations. But Geoffrey remained unruffled, reminding the archbishop that he was (honorarily, at least) both a canon of Saint-Martin and a monk of Marmoutier. "And thus," since both houses were now exempt from the archbishop's power to excommunicate, "the wise man both evaded the unjust sentence of the pontiff and proved how highly the pontiff should hold the privileges of churches." 32

Although John directed much of his discussion to inner motivation, he continued to praise the exterior and manly virtues of the Angevins in terms reminiscent of the Return from Burgundy. In his life of Geoffrey the Fair, for example, he portrayed Geoffrey as a valorous count-like Ingelger, a "comes impiger." And like the author of the Return from Burgundy, John contrasted the count's vigor with the weakness of a king. This time, however, the weak king was not the king of France but Stephen, the "false king" of England, who in his struggle to retain the throne "waned" each day, while his rival Geoffrey grew "more robust." 33

John described Geoffrey as a leader who met the traditional criteria of manly virtues. Nevertheless, he stressed that Geoffrey's most important traits were wisdom, mercy, and justice. In his prologue to Geoffrey's Life, John wrote that because Geoffrey manifested these traits, he proved himself an ideal ruler, even though he was not actually a king: "For who did not know either his clemency toward those who had been overthrown, or his mercy toward the wretched, his justice toward rebels, his strength in fighting enemies, his skill in managing things?" 34

In emphasizing Geoffrey's intellectual and moral virtues, John built on earlier twelfth-century versions of the Angevin family history. Even in the Return from Burgundy, Ingelger employed a certain rhetorical skill when he pointed out to the bishop that he was not living up to the etymology of his title, pontifex. Moreover, the first redaction of the

32. "Sic vir sapiens et injustam pontificis evasit sententiam et quanti haberet ecclesiarum privilegia comprobavit" (John of Marmoutier, Historia Gaufredi ducis Normannorum et comitis Andegavorum, 192-93).

33. "Facta est longa concertatio inter Stephanum pseudoregem et Gaufredum Andegavorum consulem: Gauf redus proficiens et semper in seipso robustior, Stephanus decrescens quotidie" (John of Marmoutier, Historia Gau fredi, 226, 230-31).

34. "Quis enim non noverit vel clementiam predicti viri in prostratos vel in miseros misericordiam vel justitiam in rebelles vel in hostes fortitudinem vel in rebus gerendis astutiam?" (John of Marmoutier, Historia Gaufredi, I73). C. Stephen Jaeger has cited John's descriptions of Geoffrey as "clemens" and "mitis" as a sign that the laity was adopting the courtly manners of the clerics in their midst (Origins of Courtliness, I 50). 
Deeds of the Counts of Anjou portrayed Fulk the Good as "peacemaking, tranquil and mild" and noted that Geoffrey the Fair was "admirable in his uprightness, notable in his justice, devoted to military deeds, extremely literate, the most eloquent among both lay and clerical persons, and generally endowed with all good morals." 35

This interest in the moral, intellectual, and-as C. Stephen Jaeger has argued-courtly virtues of the Angevins seems to have grown in increments during the twelfth century. ${ }^{36}$ John of Marmoutier, however, was the first historian of the Angevin line who explicitly attributed these traits to Ingelger. John made it clear that Ingelger was a wise and literate ruler, and in so doing he wedded an interest in rational and interior traits of rulership with an interest in mythological points of origin: "This Ingelger [was] most profound in counsel, catholic in faith, exceedingly learned in letters, strenuous in arms and great in counsel and strength." 37 Because Ingelger, the only patriarch of the family, was both learned and wise, the entire Angevin line was by implication blessed with these traits.

John of Marmoutier's interest in the moral and intellectual virtues of the former counts of Anjou was linked to his rhetorical interest in affecting the interior motivations of his contemporary audience. He wrote not simply to enhance the reputation of the Angevin line, but to instruct and move his audience as well. Indeed, in his Life of Geoffrey the Fair he presented Geoffrey as an exemplar upon whom Henry II could model his own behavior.

The earlier authors who wrote about the counts of Anjou showed some interest in moral persuasion, but their primary intention was to enhance the reputation of the Angevins-to convince an outside au-

35. "Iste fuit pacifici et tranquilli et mitis ingenii," "probitate admirabilis, justitie insignis, militie actibus deditus, optime litteratus, inter clericos et laicos facundissimus, fere omnibus bonis moribus repletus" (Chronica de gestis consulum, 34, 7I). See Jaeger's insightful discussion, which anticipated much of what I have to say here (Origins of Courtliness, 203-6). Jaeger, however, attributed this passage to Breton of Amboise (who wrote between I I 55 and I 173) rather than to Robin, who continued the first redaction of the chronicle. I am following Halphen and Poupardin in attributing the passage to Robin.

36. Chronica de gestis consulum, 35-36; additions of MS. B (redaction of Breton of Amboise, who wrote between IISS and I I73), p. I40. This latter is the passage in which Fulk the Good sends the famous note to the king, "Rex illiteratus est asinus coronatus." On the use of this proverb in the twelf th century (by William of Malmesbury and John of Salisbury and then by Breton), see Galbraith, "Literacy of the Medieval English Kings," 212-13. Georges Duby sees in Breton's passage an elaboration of the secularization of princely values and the appropriation of kingly virtues by the Angevins (Three Orders, 28990).

37. "Hic itaque Ingelgerius, consilio profundissimus, fide catholicus, litteris apprime eruditus, armis strenuus, magno consilio et fortitudine" (Chronica de gestis consulum, additions of MS. C, p. 30 n. d). 
dience of the glory and legitimacy of the dynasty. Fulk Rechin declared in his prefatory remarks, which seem to reveal a desire to justify his somewhat irregular succession, that he wanted to describe how he and his ancestors came to possess and retain their position. 38 And the introduction to the first redaction of the Deeds of the Counts of Anjou emphasized unambiguous praise: it opened with a quotation from Sallust about the need to preserve the memory of those whose "virtue is considered glorious and eternal." 39 The author of the Return from Burgundy made no clear statement of his intentions, but the legend emphasized heroic and legitimizing deeds more than motivation and moral concerns.

Despite their preoccupation with reputation, however, the first authors of the Deeds of the Counts of Anjou helped pave the way for John's interest in instruction and motivation. At several points in their work they acknowledged that the dynasty's history was not one of continuous glory, that stories from the past could help mold the character of individuals in the present, and that family characteristics did not absolutely determine one's destiny. For example, in the last sentence of his version of the Deeds of the Counts of Anjou (which ended with Fulk Rechin, who died in I I09), the first author of the first redaction explained that he had collected the record of the counts' deeds not only to glorify the Angevins but also to edify them and provide models for their imitation: "While I found these things written in hidden volumes, I could not bear to bury them with fruitless silence. Therefore I composed their deeds just as I perceived them for the honor of our lords the counts of Anjou, and I entrusted the established deeds for the edification of successors, imploring that our labor would be able to find fruit in the imitation of the best of our predecessors by our contemporaries." 40

John of Marmoutier built on these precedents, but he went much

38. "Volui commendare litteris quomodo antecessores mei honorem suum adquisierant et tenuerant usque ad meum tempus et deinde de me ipso quomodo eumdem honorem tenueram adjuvante divina misericordia" (Fulk Rechin, Fragmentum historiae, 232). Fulk's succession was irregular: he became count af ter he imprisoned his brother, Count Geoffrey the Bearded, who was subsequently deposed by the pope. Moreover, his brother had succeeded their uncle, Geoffrey Martel, so his succession did not follow the regular fatherson pattern either: see Halphen, Comté d'Anjou, 133-34, I43-51.

39. "Cum vita nostra brevis sit, memoriam eorum quam maxime longam efficere debemus quorum virtus clara et etema habetur" (Chronica de gestis consulum, 25). Italicized words were borrowed from Sallust, Catilina, 4:3.

40. "Hec ego dum in voluminibus abditis invenissem scripta, non sum perpessus infructuoso silentio tegi. Ad honorem igitur dominorum nostrorum Andegavorum consulum sicut gesta eorum agnovi conscripsi et ad edificationem successorum credidi destinanda, obsecrans ut labor noster in optimorum antecessorum imitatione a modernis valeat fructum invenire" (Chronica de gestis consulum, 67). 
further. By placing his discussion of edification and imitation in the preface rather than in a concluding sentence, he framed his entire work in a motivational way. In that preface John directly addressed the man-King Henry II of England-whose behavior he wanted to influence, suggesting that the king would find in the Angevins' family history not a continuous succession of virtuous men and glorious deeds, but a set of bad men, whose behavior he should avoid, and good men, whom he could choose to imitate. The authors of the first redaction of the Deeds of the Counts of Anjou had made a similar point, but only when they needed to justify their reasons for discussing the less exemplary members of the line, Geoffrey the Bearded and Fulk Rechin. 41

John also moved beyond the earlier authors in his explicit assertion that although his history provided models for imitation and examples for edification, those models could take effect only if they penetrated the surface of behavior, affecting the king's interior motivations. John wanted to instigate imitation and kindle caution. His use of these words, which appear in other works by his contemporaries at Marmoutier as well, placed new emphasis on the inner self and the role persuasion could play in moving that inner self:

When good history refers to good things, the solicitous listener should be instigated to imitate the good or, recollecting the bad deeds of the depraved, the religious and pious listener or reader will be kindled, nonetheless, to avoid what is noxious or perverse, to execute more clearly those things that are good and that he knows to be worthy to God.

These things, my lord king, I . . wrote down for the honor of the counts of Anjou, our lords, and for the utility of those who hear them and for the instruction of your character, so that you will assume a good example and a better end from the good ones, and from the bad ones you will be made aware of a bad entrance or path lest you come to the same bad end. 42

4I. Chronica de gestis consulum, 62-63. Along similar lines, Guibert of Nogent indicated that he wrote his Memoirs to edify others by providing bad and good examples: De vita sua, I 29-30.

42. "Sive enim historia de bonis bona referat, ad imitandum bonum auditor sollicitus instigatur, seu mala commemorans de pravis, nichilominus religiosus ac pius auditor sive lector de vitando quod noxium est ac perversum, ipse solertius ad exequenda ea que bona sunt ac Deo digna esse cognoverit accenditur," "Hec ego . . . ad honorem Andegavorum consulum, dominorum nostrorum, et ad utilitatem audientium et instructionem morum tuorum, domine mi rex, conscripsi, scilicet ut ex bonis bonum sumas exemplum et meliorem exitum et ex malis malum caveas introitum sive incessum, ne incidas in eorum pessimum finem vel exitum" (Chronica de gestis consulum [additions, preface of John of Marmoutier], 163, 164). 
John of Marmoutier was not the only author in Henry II's circle who took an interest in internal motivation. Indeed, it is not surprising that people in the king's entourage addressed this issue. Henry and his associates helped lead the way in the twelfth-century revival and expansion of legalistic and bureaucratized forms of government. 43 Bureaucratic governments have their advantages, but they also have their costs: government officials, as John of Marmoutier was well aware, may not always behave in ways that serve the interests of their ruler and of the people. ${ }^{44}$ Such men exercised many of their official functions in the absence of the ruler himself; their loyalties to him were more impersonal and attenuated than were those of feudal vassals. Because sophisticated forms of political organization rely on impersonal ties, a desirable goal for twelfth-century rulers and intellectuals was to mold people-potential bureaucrats, ordinary subjects-who would behave in accordance with principles of law and justice even when the eye of the ruler was not watching and when the policing arm of the government was not striking. Internal motivation, rather than mere external restraint, was a desirable form of inhibition for the society that was taking shape in the mid-twelfth century.

The differences between John's preoccupations and those of earlier authors who wrote about the counts of Anjou point to a mounting interest in interior concerns. Note, however, that Henry II's court was not the only context for John of Marmoutier's ideas. As I show in chapters 4 and 5, Marmoutier's twelfth-century literature abounded with discussions of internal motivation.

This growing interest in internal motivation did not supplant or stand in opposition to the interest in group legitimacy. Rather, Marmoutier's monks explored the two themes simultaneously. The multiplicity of competing groups in twelfth-century society meant that one's place in the world and one's code of behavior were not necessarily predetermined. The individual was left with choices: whether to become a black Benedictine or a Cistercian, whether to side with the cathedral of Tours or the abbey of Marmoutier, whether to ally with the Angevin count or the French king. Some of the vernacular epics of the period successfully portrayed these multiple perspectives, giving equal weight, for example, to the demands of feudal ties and of family.

43. On the growth of government in the twelfth century, see Warren, Governance of Norman and Angevin England, and Dunbabin, France in the Making, 277-86.

44. John of Marmoutier, Historia Gaufredi, I 85-91: Geoffrey demonstrates his liberality by giving ear to a poor man, who tells him that his agents are mistreating and cheating his subjects. For discussions of this well-known passage, see Dunbabin, France in the Making, 285-86, and Duby, Three Orders, 280-82. 
These works suggested that conflicting loyalties-to overlord and family, to church and king-forced the individual to recognize that the world did not provide a perfect system of order. Men and women had to find that order within themselves. 45

John of Marmoutier's writings do not represent a break with earlier notions of group legitimacy or with aristocratic notions that blood helped shape who one was. Aristocratic ideas about blood and class were intensifying at the end of the twelfth century, and John's writings were thoroughly consistent with these developments. ${ }^{46}$ Nevertheless, John portrayed his royal patron in active dialogue with his heritage and group identity. Henry II had the advantage of inheriting the blood of the illustrious Angevin counts, but he also had the responsibility of shaping his own career and character within the limits defined by his dynasty's history. The king was privileged to be the descendant of special men of a special dynasty, but he was also responsible for his own choice to live up to the potential his heritage provided and to follow the examples of the good men who had preceded him.

45. See discussion of epics of revolt in Bezzola, "De Roland à Raoul de Cambrai," I9I213; Calin, Old French Epic of Revolt, esp. I 16, 140 ff. For similar discussion of alienation in twelfth-century romance literature, in which the individual had to resolve conflicting codes of behavior, see Morris, Discovery of the Individual, $133-38$

46. Duby, Three Orders, 27I-92. 